\title{
THE GREEN HEART AND THE DYNAMICS OF DOCTRINE
}

\author{
Arnold van der Valk and Andreas Faludi
}

\begin{abstract}
The Green Heart is the most pronounced of Dutch planning concepts. It rests on an organic metaphor that for over 40 years now has been at the heart of Dutch national planning. Although the object of much debate, the national government has decided recently to stick to a restrictive policy for the Green Heart, for the next decade anyhow. The authors shed light on the apparent continuity of policy by invoking the concept of planning doctrine. Planning doctrine is a framing device for planners. It combines substantive as well as procedural aspects. In developing the notion of planning doctrine, the article draws on the work of Kuhn, Lakatos and Laudan.
\end{abstract}

The Green Heart is alive and kicking. It has a lasting appeal to the Dutch planning community. This is the conclusion from the Green Heart Debate initiated by the Minister for Housing, Spatial Planning and the Environment. A government document called "The Randstad and its Green Heart: The Green Metropolis", published in September 1996, points in the same direction. Meanwhile, the government has translated this into the first draft of a planning key decision to update the Fourth Report on Spatial Planning Extra to cover the period of 2005 to 2010.

Randstad and Green Heart, or, as Gerald Burke (1966) has it, the "Greenheart Metropolis", have stirred the imagination of planners ever since the fifties. The Green Heart in particular is the most pronounced of Dutch planning concepts. It refers to the open area surrounded by towns and cities forming the "Randstad", or rim city. This Randstad in the Western Netherlands has been an urban network long before network had become an idea of good currency. The term Randstad as such dates from the thirties. The Working Commission for the Western Netherlands (1950-1958) took the decisive step of designating the open area in the middle as the Green Heart. There is a metaphor underlying this name, that of the country as a body, the well-being of which vitally depends on the health of its heart. Randstad and Green Heart thrive on this metaphor.

Neth. J. of Housing and the Built Environment, Vol. 12 (1997) No. 1. 
Figure 1. Randstad + Green Heart $=$ Green Metropolis

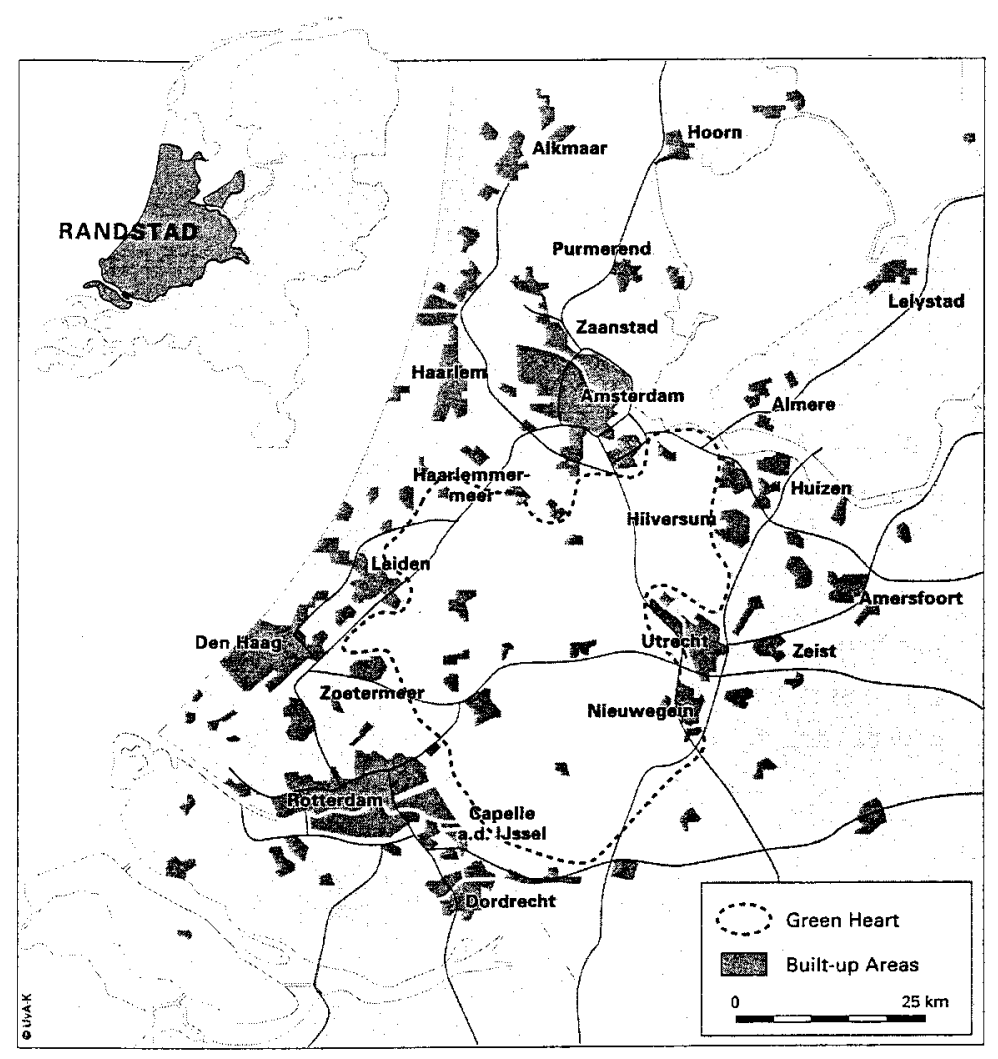

We give an account of the lasting love affair between the Green Heart and the Dutch planning community. The key to understanding strategic planning is that it works through framing thought and action. We call that which achieves this feat a "planning doctrine" (Faludi and Van der Valk, 1990 and 1994). Planning doctrine refers to a coherent set of views about the present shape and the future development of an area, alongside strategies for the management of growth. All being well, a doctrine guides the thoughts and actions, not only of professional planners, but also of politicians, opinion leaders and the public at large.

However, planning doctrine is not without its dangers. Theoretical considerations and empirical evidence both suggest that a defensive, and hence "doctrinal" attitude has its drawbacks. Sustaining the notion of a doctrine and opposing the tendency of being doctrinal, as we do, surely seems paradoxical. This is where theoretical reflection about planning doctrine as a framing device analogous to "paradigms" or "scientific research programmes" comes into its own. Such reflection leads to a 
distinction between the hard core of a doctrine and the more variable concepts surrounding it. It also lets us identify various models of doctrinal change as a result of what Alexander and Faludi (1990) describe as "doctrinal discourse" (see also the concept of "frame-reflective discourse" in Rein and Schön, 1986 as well as Schön and Rein, 1994).

The paper comes in three parts. In part one we give a historic account of the Green-Heart metaphor leading up to a situation where the Netherlands can boast a reasonably mature doctrine. In such a situation, a vital issue is that of how such doctrines are modified, changed or replaced. Is revolutionary change the only consequence? This seems to be a corollary of the analogy with Kuhn's paradigm thesis. Is evolutionary change a plausible alternative? In order to answer these questions, we consider models of doctrinal change in part two, drawing on Willem Korthals Altes (1995). We accept his argument that Dutch doctrine is evolving in evolutionary rather than revolutionary fashion. Indeed, in part three we interpret the present revival of the Green-Heart concept as part of an evolutionary process. The conclusion is hopeful. Current doctrine evolving around the Green Heart seems to be adapting to the challenges of the twenty-first century.

\section{The making and the reception of the Green-Heart metaphor}

The first documented use of the term "Randstad" is in a 1938 letter to the government written by the aviation pioneer, Albert Plesman. In it, Plesman argued for a central national airport within the ring of towns and cities in the Western Netherlands. Plesman's source of inspiration had been leading planners: L.S.P. Scheffer, head of the Amsterdam planning department, and Th. K. van Lohuizen, the chief of his research section. Plesman's acquaintance with Scheffer dated from 1919 when the latter had done some design work for the aeronautics exhibition in Amsterdam North organized by Plesman. Van Lohuizen had been the author of maps showing the most highly urbanized municipalities in the Western Netherlands as early as 1924. The maps had indicated the contours of the ring, or rather the horseshoe of towns and cities which Plesman described as the Randstad. These maps had been exhibited throughout the country. However, documents of that period do not mention the term Green Heart, using the flat term "central area" instead.

The "invention" of the Green Heart had to wait until 1956. The spiritual father of the concept was the then director of the Bureau for the National Plan, Jasper Vink. The Working Commission for the Western Netherlands (1953-1958) debated whether to maintain the central area open for agricultural use. Assembling the planning elite as it did, this commission set out the directions of the development of the Netherlands until 1980.

Vink was an advocate of keeping the central area open. Trying to add weight to his arguments, he invoked the example of the Green Belt around London. He also sought to strengthen his hand by describing the open area in the middle as the "commons" of the Randstad. At that time, the term "Green Heart" was mentioned almost in passing. In their final report, the Working Commission continued to use it, but 
Figure 2 Contours of the Randstad on a map depicting population growth, by ir. Th.K. van Lohuizen (1924)

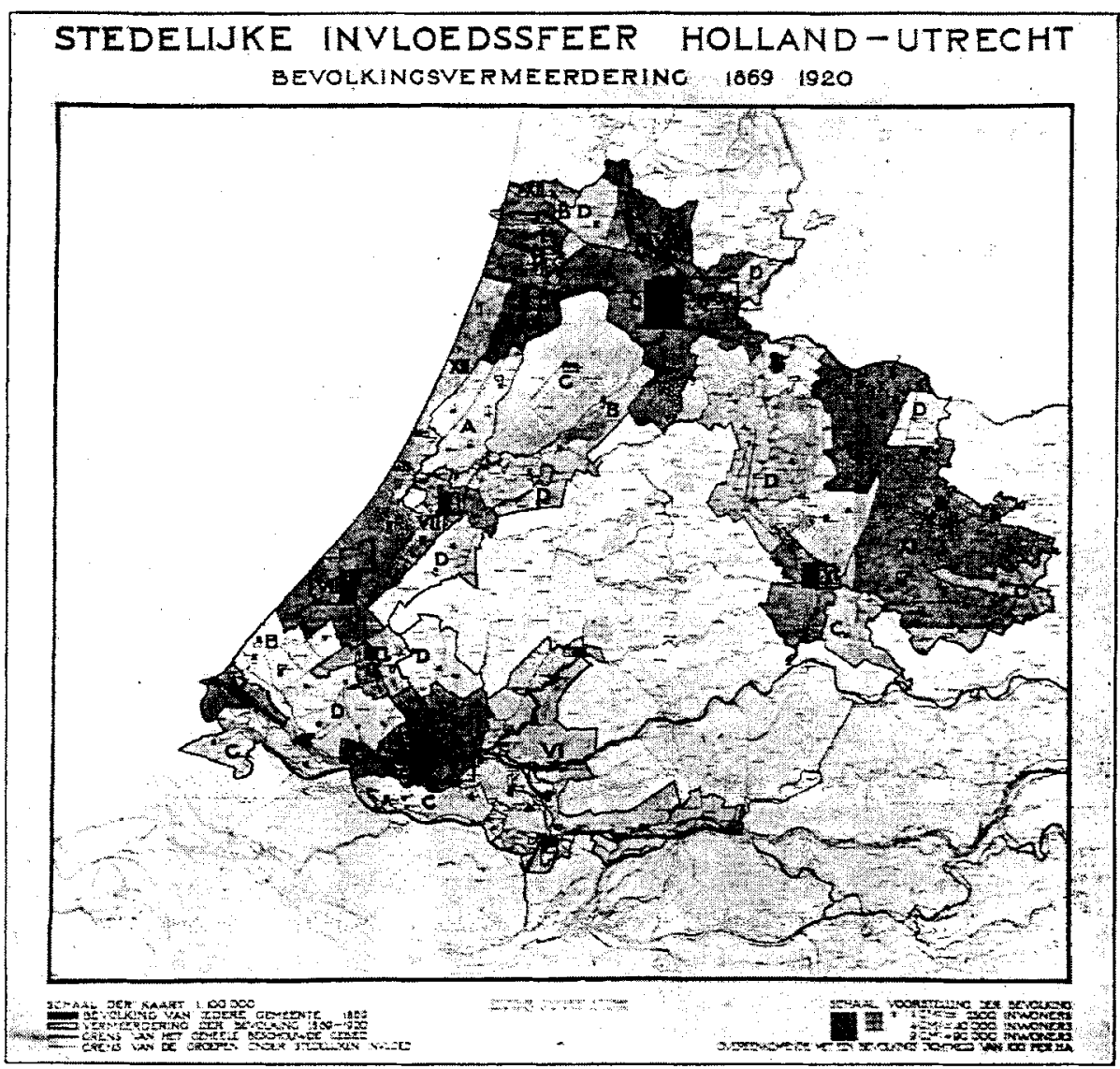

Source: Archives Th.K. van Lohuizen, 1924.

they made light play of the imagery of a heart. They simply pointed out that the structure of the Randstad was that of "...a ring of larger and smaller agglomerations... around the pasture lands of Holland and Utrecht forming the green heart of the whole" (Werkcommissie Westen des Lands, 1958: 15). For as long as possible, the central area should be agricultural and a reserve area for future urban development.

Studies and policy documents of the sixties and seventies rarely invoke the term Green Heart. Mostly, the Bureau for the National Plan used terms such as the "agricultural central area" and the "central open area". So its acceptance as a 
planning concept has been a slow process. Without elaborating, the 1960 "Report on Physical Planning in the Netherlands" was in favour of preserving the mainly agricultural central area. The emphasis was on the management of urban growth. The government and the provinces were lukewarm about a 1963 brochure by the Dutch Royal Tourist Association A.N.W.B., "Holland's Green Zone", arguing for a park landscape in the core of the Randstad (Jaarverslag 1961, 1962: 59). During this period, rural planning was still the exclusive domain of the Ministry of Agriculture and Fishery. Planning journals made more and more references to the Green-Heart concept in the sixties, but the "Second Report" of 1966 continued to use the term "Central Open Area". The latter is larger than the area enclosed by the horseshoe of towns and cities that the Working Commission has described as the Green Heart.

The government referred to the "Central Open Area" in fairly vague terms. The area was said to be "... a large and sparsely urbanized, predominantly agricultural area". The area should remain open because the proposed urban development in the Randstad required open space on a concomitant scale. Otherwise, people might set their minds against large-scale urban development (which the planners regarded as necessary). At the same time, the Second Report proposed a dense network of roads criss-crossing the central area. Evidently, the government was still far from appreciating its landscape and ecological value. The main concern was to keep the option of future urban development open. The concept of a "Central Open Area" failed to make an impression on the inhabitants and politicians of the provinces concerned. The provincial structure plans of the province of South Holland dating from the seventies ( 70 per cent of this province belonged to this area!) made hardly any mention of this concept (Ahsmann and Zonneveld, 1990: 161).

The attitude of provincial and local politicians as well as of developers and the inhabitants of the Green Heart was one of benign neglect. As a result, there was much development taking place around 1970 that took the form of housing, market gardening, roads and industrial parks. It was the Den Uyl cabinet (1973-1977) who came out strongly against suburban growth, in particular in the Green Heart. Containment became the watchword in the Western Netherlands. The government scrapped many ambitious road proposals. The successive parts of the Third Report on Physical Planning (coming out during the period 1973 to 1983) emphasized more and more the intrinsic value of the Green Heart. Even more importantly, from 1973 onwards, provincial structure plans gave priority to keeping the Green Heart open, thereby taking account of its potential for nature preservation, environmental protection, recreation and agriculture. During this period, planning journals published lively debates between proponents and opponents of metropolitan development in the Western Netherlands. Abroad, the Randstad/Green Heart concept had already become famous. This was due to the publication of "Greenheart Metropolis" (1966), the book by Gerald Burke mentioned above. Even more important was the inclusion of the Randstad as one of seven world cities discussed in the best-seller under the same title by Peter Hall (1966).

Since the mid-eighties, the term Green Heart has replaced that of central area in national government publications (Zonneveld 1991b: 97). This reflects the growing appreciation of the intrinsic qualities of this area. The Fourth Report on Physical 
Planning dating from 1988 (VINOa, 1988: 118 ff.) was the first to consider the internal differentiation of the Green Heart. At the same time, the Fourth Report no longer excluded urban development on the fringes of the Green Heart. Finally, the report explored the relations between the area itself and urban development, as well as relations with rural areas outside. In the core of the Green Heart, the report designated a number of areas of ecological value. There was also mention of the role of water and of agricultural use. Some settlements in the Green Heart were designated for catering to housing need.

National government took another important step by drawing a firm borderline around the Green Heart in 1990. Approximately 70 per cent of the area $(100,000$ hectares) was still in agricultural use. In addition, the government set aside 15 per cent for nature areas. Within its new borders, the Green Heart had 673,000 inhabitants. Its population compares to that of the city of Rotterdam $(667,000$ inhabitants on January the first, 1993). The Randstad as a whole had a total of six-and-a-half million inhabitants. The population density in the Green Heart was 460 inhabitants per square kilometre, as against 1,680 in the surrounding city regions. Most new housing and industrial development had gone to the six largest communities in the Green Heart. The West of the Green Heart was experiencing rapid growth of market gardening. Economically speaking, the Green Heart formed an integral part of the surrounding city regions. There were something like 150,000 commuters between the Green Heart and the Randstad. This came to light in an analysis of commuting patterns. In 1992, the number of people working in the Green Heart was 206,000. Since then, this number has increased substantially.

The Green Heart spans three provinces and 70 municipalities. As the Green Heart is presently defined, the province of South Holland is for 60 , as against the previous 70 per cent, part of it. For North Holland, the equivalent figure is ten per cent and for Utrecht 31.

Since 1990, then, the Green-Heart policy has been twofold:

1. Keeping the agricultural central area open for the sake of urban dwellers and so as to form a green counterweight to the urban development around it.

2. Developing the area in such a way as to optimize the benefits for the inhabitants of both the city regions as well as the Green Heart itself. The means to achieve the latter are, among others, the integration of agricultural and other "green" uses (Randstad en Groene Hart, 1996: 71).

An important change of policy concerns the agreements reached between national government and the provinces of South Holland, Utrecht and North Holland with regard to caps on development. Within the Green Heart as presently defined, the restrictive policy allows for a further 17,000 homes between 1995 and 2000 . All of them must be built within the contours drawn around existing settlements, as indicated on provincial structure plans. Dutch government has prescribed a restrictive policy for the Green Heart and some other vulnerable open areas. The purpose is to put up barriers against urban sprawl in the Green Heart. The national government has a strong say in the designation of areas to cater to new development 
by means of defining the so-called extension contours. Normally, extension contours leave the towns and villages wanting to expand no other choice than high-density development. The urban communities in the Green Heart in particular complain that this represents an unacceptable intrusion in their autonomy as regards planning. Under Dutch law the municipalities have the right and, indeed, in many cases the duty to adopt binding land use plans. However, these must fit in with the indicative provincial structure plans and the so-called planning key decisions taken on national level. Traditionally, both the provinces and the national government abstain from using their right of issuing directives concerning the content of plans drawn up by other levels of government. In the case of the restrictive policy though, since 1990 the unwilling provinces and municipalities receive frequent threats that national government might invoke this legal weapon.

The government has good reasons for tightening-up on planning control (Cf. Needham, 1995). Previously, the restrictive policy has always been articulated by means of formulas for calculating housing need per region and per municipality. Making good use of the uncertainty of population forecasts and the complexity of the system of housing allocations, municipalities had often been able to subvert provincial policies (Glasbergen and Simonis, 1979; Rijksplanologische Dienst, 1996b: 25). As a consequence, population growth in the Green Heart between 1972 and 1992 had been 160,000 , only slightly less than the total of 171,000 in the surrounding city regions. In relative terms, the growth of the Green Heart communities had been even more spectacular: 31 per cent, as against a mere four per cent in the city regions! Naturally, the absolute figures give an altogether different picture. The same period 1972-1992 had seen the building of 105,000 homes in the Green Heart, as against 571,000 in the city regions. The most highly urbanized communities within the Green Heart are Alphen aan den Rijn and Gouda, both of which had approximately 60,000 inhabitants in 1996. The apparent discrepancy between population growth and the number of new housing units is easy to explain. The average household size in towns and cities has fallen.

The 1996 annual report of the National Spatial Planning Agency claims that the containment policy for the Green Heart is beginning to bite. In 1991-1995, at 0.9 per cent, population growth in the Green Heart has been hardly more than in the surrounding urban areas, where that figure has been 0.8 per cent (Rijksplanologische Dienst, 1996a: 111). Population growth is concentrated in the six most urbanized municipalities within the Green Heart. On the other hand, there has been a failure to stop the process of fragmentation of open space due to infrastructure. The municipalities blame central government for being inconsistent. On the one hand, the government wants the municipalities in the Green Heart to restrict growth. On the other hand, government itself initiates incursions into the Green Heart, like the high speed train, the doubling of motorways and the relocation of horticultural areas near Rotterdam and Utrecht.

Recently, parliament has approved the high speed train going trough the Green Heart. Controversy over this decision has raged for many years. Since opinions as to this route between, and even within, political parties differed widely, the decision was left more or less open during the formation of the centre-left cabinet in 1994. 
Table 1 Population growth: relative annual average growth 1972-1994

\begin{tabular}{lrrrrr}
\hline & $72-77$ & $77-82$ & $82-87$ & $87-90$ & $90-94$ \\
\hline Green heart & $2.4 \%$ & $1 \%$ & $0.9 \%$ & $1 \%$ & $0.9 \%$ \\
Cities & $-0.5 \%$ & $0 \%$ & $0.2 \%$ & $0.6 \%$ & $0.8 \%$ \\
Netheriands & $0.8 \%$ & $0.7 \%$ & $0.5 \%$ & $0.6 \%$ & $0.8 \%$ \\
\hline
\end{tabular}

Source: Rijksplanologische Dienst, 1996b, p. 25.

Although the minutes of the cabinet meetings are secret, well-informed journalists found out that on this issue the cabinet, too, was divided. The Minister of the Environment and the Minister of Agriculture opposed the route through the Green Heart proposed by the Minister of Transport, Public Works, and Water Management, backed by Economic Affairs and the Prime Minister. The route through the Green Heart was designated the "preferred alternative" even so. However, two other options were given serious consideration. One ran alongside the existing intercity rail link through the built-up area, the other one alongside existing motorway links on the outskirts of the built-up area. Arguments in favour of the "preferred alternative" were that it went straight from the Seaport of Rotterdam to Schiphol Airport, that the costs were relatively low and that, already in 1994, the necessary negotiations with the municipalities in the Green Heart had been completed. To the economic lobby in the cabinet and in parliament, these arguments seemed decisive. The opponents cast doubt on the alleged savings in terms of time and money. They pointed out the detrimental effects of the "preferred alternative" on the landscape and on water systems. After complicated negotiations, the cabinet arrived at a compromise. The city of The Hague, after all the seat of government, will not be on the route of the high speed train. The "preferred alternative" was presented to parliament, but with an important and costly addition. To ease the pain for environmentalists, 1000 million guilders were set aside for a ten-kilometre tunnel under the pastures north of the town of Zoetermeer. The obvious inconsistency with the statutory Green Heart policy was accepted. At the beginning of the parliamentary debate in the summer of 1996, it seemed as if all options were open. The cabinet faced a majority against the route through the Green Heart. However, as ever so often, a meeting behind closed doors between the leaders of the coalition parties averted a potential political crisis. Since the opponents of the Green Heart were divided over which alternative they preferred, the compromise route through the Green Heart, but with a tunnel under the most vulnerable part, carried the day. Although regrettable in itself, in a way this compromise stregthens us in our opinion that the Green Heart is alive and kicking. After all, what other reason could there be for a tunnel under pasture lands but the high value attached to keeping the Green Heart open?

In the wake of the strict demarcation of the Green Heart which has led to this compromise, two interpretations of the concept have emerged. First, there is the Green Heart endorsed by national policy, approximating 150,000 hectares, including 
water surfaces. The second interpretation is the popular one that includes all open space between the cities of Amsterdam, Rotterdam, The Hague and Utrecht. It mirrors the rather vague notion of the Green Heart in old government reports. A publication by the National Spatial Planning Agency recognizes the existence of these two interpretations (Rijksplanologische Dienst, 1996b: 9).

This brings us to the role of the profession in formulating and propagating the Green Heart. One should certainly not underestimate that role. Targeting the government, provincial administrations and local communities as well as the public at large, planners from the National Spatial Planning Agency have been incessant campaigners for the Green Heart. From the middle of the sixties, the planning literature has paid much attention to the concept. Journals gave scope to both its proponents and the opponents for airing their views. When the Fourth Report came out in 1988, the planning community embarked on a new round of debates.

Browsing through the press and the planning journals of the recent past, we can discern three camps: the fundamentalists (Hands off the Green Heart!), the pragmatists (An ounce less green is not the end of the world!) and the heretics (Going by train from Amsterdam to The Hague, I see too many cows!). The fundamentalists want to call a definite halt to urban development. They find themselves in the company of nature preservationists. The latter wish the Green Heart to return to its original state, when it consisted of peat bogs and primeval forests. The fundamentalists want to strictly enforce the border around the Green Heart, as well as the contours around Green Heart settlements. The present Minister of Housing, Spatial Planning and Environment, Margaretha de Boer, sympathizes with this movement.

The pragmatists are willing to take account of a looming shortage of building land and more generally the need to relieve congestion. They emphasize that, from the point of view of ecology and/or cultural history, not all areas within the Green Heart deserve the same degree of protection. Being an opinion leader from this camp, Van der Cammen pleads for more intensive recreational use of green areas for "... nature camps, a range of sports and fitness facilities, shelters for walkers, mobile home parks, conference and education centres..." (NRC Handelsblad, February 23, 1992). We ourselves have argued for so-called growth regions on the inner flank of the Randstad, among other places. Growth region refers to an area, comprising the territory of several municipalities, where government promotes housing much in the same way as it has previously stimulated housing in the growth centres. Designating growth centres such as Zoetermeer and Nieuwegein as the engines of growth regions seems an obvious path to take. The reason is that growth centres possess the know-how for managing growth. Caps on the development of small communities are more credible if growth regions are catering to the need of families leaving the cities in search of suburban homes (Van der Valk and Faludi, 1992: 122).

And what about the heretics? They take pleasure in poking fun at the apparent dogmatism of the Green Heart policy. The columnist and economics professor E. Bomhoff points out the great untapped potential of the peat polders. The art historian Vincent van Rossem even goes as far as arguing for a laissez-faire policy, like in Los Angeles. Some architects have taught the fundamentalists the fear of God by 
suggesting to spread the Randstad evenly over the Green Heart, like a carpet on a bare floor, calling this the "carpet metropolis" (Cf. Garreau, 1991).

In the fall of 1995, the Minister of Housing, Spatial Planning and Environment organized a public debate on the Green Heart. All those concerned, including the planning profession, participated. What clearly emerged was that the Green Heart policy enjoyed broad support, especially among professional planners.

In conclusion, in the fifties and sixties, the Green Heart was no more than an imaginary template of the Randstad, the ring of towns and cities of the Western Netherlands. In the Green Heart, agricultural interests called the shots. There was support for keeping the Green Heart open, based on vague considerations of social hygiene. But if the need should arise, the fringes of the Green Heart could be turned over to urban use. In the seventies, national and provincial policy paid increasing attention to the intrinsic value of the Green Heart. Nature, landscape, cultural history, recreation and a clean environment were considerations on a par with agricultural use. Perhaps this was due more to debates in planning journals and the daily press than to government policy. Even so, since the seventies, the Green Heart enjoys broad recognition and the support of the general public. Since then, the Randstad has become inconceivable without its complement, the Green Heart. Since publication of the Fourth Report, policy-makers pay more attention to the pair of concepts Randstad/Green Heart than ever before. Strikingly, the most recent national policy recognizes that, living in the core of a metropolis, the population of the Green Heart is urban and not rural in character.

\section{The dynamics of planning doctrine}

The image of a Randstad with a Green Heart forms the core of a complex of planning concepts and related ideas concerning how to go about planning. These ideas appeal to our common sense and evince associations that are almost wholly positive. This is not only true for planners who have hatched this egg but also for politicians and the public. When asked, over 80 per cent of the Dutch population supports the Green Heart (Verslag van de Groene Hart gesprekken, 1996: 21). Faludi (1987) has labeled this phenomenon as planning doctrine. Planning doctrine refers to a coherent set of ideas which over considerable periods of time help in conceptualizing the spatial structure and development of an area and how to handle both of them. Planning doctrine has two faces. One relates to spatial structure and processes, the other to the planning process. We describe the first, or spatial dimension of doctrine as the principle of spatial organization. The second, organizational and procedural dimension we refer to as planning principles. A spatial organization principle synthesizes current planning concepts into one overall notion reflecting the specific nature of the plan area. Planning principles are notions concerning the preparation, the form and the effects of having plans.

The notion of a planning doctrine has emerged during a study of the effectiveness of the 1976/1978 Urbanization Report, the key part of the Third Report 
(Faludi, 1987: 128). Surprisingly, the Urbanization Report turned out to have been an effective guide action. This was a surprise because the Urbanization Report was short on concrete directives. Thus, from a planning-methodological point of view, it seemed to fail the test of an effective plan. The plan was effective even so, as evidenced by the fact that the growth centres came approximately where the government had said they should. Urban renewal, too, as well as the policy of containing suburban development, went approximately as planned. To explain this success, Faludi pointed out the existence of an appealing image of the intended spatial structure that he described as planning doctrine.

The literature is replete with similar concepts under names like leitmotiv, planning philosophy and Weltanschauung. The term planning doctrine as such is not new either. Amongst others Foley (1963) and Friedmann and Weaver (1979) have used it before. However, it has never been the object of sustained theoretical reflection. Alexander and Faludi (1990) have taken the first steps in this direction. Willem Korthals Altes in "Dutch planning doctrine in the fin de siècle" (1995) has advanced our understanding of planning doctrine. Before applying his theoretical insights to the debate concerning Randstad and Green Heart, we need to consider the notion of planning doctrine as such.

The central issue is whether planning doctrine evolves around a core that is necessarily static. If so, then change will always be abrupt and revolutionary. Alternatively, we can assume that over time the core can undergo a complete but gradual metamorphosis.

Invoking examples from a number of countries and metropolitan regions, Alexander and Faludi have identified criteria of a mature planning doctrine. We can speak of a mature doctrine if a responsible authority adopts it and applies it to its area of jurisdiction. In addition, this planning subject must hold on to doctrine over considerable periods of time. The subject must allow doctrine to shape day-to-day policy. The reverse is also true: spatial policy can be coherent and sustainable only where it builds on doctrine. Of course, in a democracy no planning agency can hold on to doctrine without that doctrine receiving political support.

To appreciate how doctrine develops and works, Alexander and Faludi have drawn on Thomas Kuhn and Imre Lakatos about the role of paradigms and scientific research programmes (see also Faludi, 1987: 130-131). Like a paradigm, planning doctrine acts as a guide post in identifying and solving problems. According to Kuhn (1970), for as long as scientific researchers work with standard problems and solutions within the dominant paradigm, we can speak of "normal" science. However, according to Kuhn, eventually normal science fails to come up with adequate answers. This creates what he calls anomalies. Dissident researchers grasp the opportunity and develop competing paradigms that account for such anomalies. In such cases, a scientific revolution is a distinct possibility. For the scientific elite that has thrown its weight behind the existing paradigm, such a revolution has dire consequences. A new elite is coming in their place.

Lakatos has modified the theory of Kuhn. He suggests that revolutionary change is a rare phenomenon. The explanation lies in the distinction between a hard core of immutable principles, described as "negative heuristics", and a protective outer layer 
subject to change called "positive heuristics". It is positive heuristics that enable the researcher to adapt ideas so as to accommodate change. In this way, the research programme adapts to new circumstances, and the danger of a revolution dissipates. The protective layer of positive heuristics absorbs the impetus of change. A revolution is still a possibility, but only if the hard core of a research programme comes under fire. According to Lakatos though, such debates at knife's edge are rare.

Alexander and Faludi draw on the whole gamut of concepts discussed above: anomalies, positive and negative heuristics and revolutionary change in science. In planning, too, doctrine can be subject to criticism, leading to increasingly tense debates and finally the replacement of one doctrine by another. (For another application of such notions to the rise and fall of what he calls "conceptual complexes" see Zonneveld, 1991a.) As with scientific research programmes, they say that there is a distinction between the hard core of a doctrine and the protective layer of concepts open to change. The situation in planning is "normal" for as long as it is possible to find solutions to problems within the framework of existing doctrine. Similarly, debates on planning issues can become more and more heated, culminating in the rejection of existing doctrine and its replacement with a new one. Where this happens, Faludi and Van der Valk (1994: 23) ask whether the step from one doctrine to another can be subject to rational considerations.

This question is highly relevant in view of the dangers associated with the pursuit of a doctrine. Doctrine promotes conservative sentiments. The group acting as its standard bearer has a growing stake in sustaining it. Where doctrine prevents creative solutions to new problems from being adopted, there the danger is that of deepening conflict with the proponents of alternative views. Here we are up against a paradox. The value of doctrine lies in its ability to convince, in the comprehensiveness and the coherence of the central metaphor on which it rests and of the concepts arraying themselves around it. These are necessary preconditions for pursuing rational planning within the context of a doctrine. At the same time, doctrine can be an impediment to rational choice. However, the paradox is more apparent than real. Critical-rationalist canons of science demand that the core ideas of a doctrine must undergo stringent tests. The criteria are those of plausibility, consistency, reliability in the light of empirical evidence, and equity.

Application of these criteria points the way as to how to guard against the deterioration of doctrine as a framework for decision-making. At the same time, the opposite, a doctrine that is totally open, is not possible either. The justification of doctrine relates to its role in generating support for certain types of planning solutions, thereby excluding other solutions. Alexander and Faludi conclude that, up to a point, doctrine can be open to change without the metaphor at the core of doctrine losing its appeal as an interpretative framework and a leitmotiv. Of course, this does not mean to say that doctrines cannot deteriorate into blueprints, losing their force of conviction in the process.

Now, Korthals Altes (1995: 42) points out, first, that Alexander and Faludi impose mutually incompatible requirements on open doctrine. A quality of planning doctrine is its capacity to limit the scope of decision-makers. Metaphorically 
speaking, they walk with blinkers on, blinkers that protect them from becoming confused by the overwhelming complexity of unstructured reality. Paradoxically though, the advocates of an open doctrine want to take the blinkers away. Second, Korthals Altes criticizes the assumption of revolution being the only path to changing planning doctrine. He draws on arguments derived from theories about the operation of metaphors, communication theory and scientific change.

Korthals Altes asserts that the users of doctrine are constantly re-interpreting the concepts of which it consists. Most of the time, this re-interpretation does not proceed by leaps and bounds. Rather, change is gradual. He refers to criticisms of Kuhn by Laudan $(1982,1984)$. Kuhn fails to explain the emergence of a new consensus, once a scientific revolution has occurred. Rather than being revolutionary, such as Kuhn suggests, Laudan sees change as piecemeal and as a process of learning and negotiation. In this whole process, everybody makes use of rhetorical figures of speech to overcome language barriers.

This implies that in the long term even the central metaphor underlying planning doctrine, and not just the protective belt, can undergo change. So an open, malleable doctrine comes within reach. Of course, this poses the thorny question of how, at any given time, we can establish whether we are still talking about the same doctrine.

The views of Korthals Altes correspond to those of the sociologist Anthony Giddens about the "duality of structures". Accordingly, societal structures are not a category apart from societal action. Rather, structures give meaning to action, whilst at the same time action can lead to a re-interpretation of structures.

Summarizing the contribution of Korthals Altes, we conclude that there are two possible models of doctrinal change. One model builds on the notion of stable doctrines and assumes fundamental change to mean a revolution. The other model assumes doctrines to be malleable. Here change is gradual and non-revolutionary.

Analysing Dutch doctrine in the fin de siècle has led Korthals Altes to conclude that it follows the evolutionary model. The end of the fifties witnessed the emergence of a mature doctrine based on Randstad and Green Heart. Concomitant planning principles concerned the management of urban growth. By the beginning of the seventies, these principles had become operational. A decade later, there was doubt concerning the wisdom of some of the principles underlying growth management. People were apprehensive of the great cities losing their vitality and potential. The planning community was toying with the idea that growth management and the role of national housing policy had reached the end of their "policy life cycles". The search was on for new topics for national planners to consider. The Fourth Report on Physical Planning (1988) formulated these ideas. The new focus was on the competitive position of Dutch cities within the Single European Market due to come into effect on January the first, 1993 (what with a misnomer has often been called "Europe 1992"). So at the end of the eighties, the signs were those of an imminent doctrinal revolution.

With the coming of a new government and the drafting of a document supplementing the Fourth Report, classic themes re-emerged. They were the management of urban growth, the reduction of auto-mobility and the maintenance of the Green 
Heart. So the planning doctrine was sustained. Massive changes in housing finance, implying the relinquishing by the government of much of its steering capacity, have had no appreciable impact so far on doctrine. Whether this will remain so is of course a moot point. Be that as it may, the merit of Korthals Altes is that he opens up the perspective of doctrine taking an evolutionary path into the twenty-first century. Below we are going to analyse the most recent government proposals for the development of the Randstad and Green Heart in the light of Korthals Altes' patterns of doctrinal development.

\section{Greenheart Metropolis revisited}

September 1996 has witnessed the publication of a supplement to the budget for housing, spatial planning and environment, "The Randstad and its Green Heart: A Green Metropolis" (Randstad en Groene Hart, 1996). In it, Minister Margaretha de Boer provides a perspective for 2005-2010, the last quinquennium to which the Fourth Report and the Fourth Report Extra apply. It is meant to be a frame of reference for government decisions concerning housing, the environment, open space and infrastructure. Negotiations preceding the budgets for 1998 and thereafter will be the vehicles for further operational decision-making. This document forms the basis for the review of the planning key decision updating the Fourth Report Extra (Actualisering planologische kernbeslissing Vierde nota extra). The first version of this newest planning document reached parliament at the very end of 1996. At the same time, the document provides clues also for long-term planning. The National Spatial Planning Agency has taken up long-range planning in a project under the telling title "Netherlands 2030" (Rijksplanologische Dienst, 1996c).

The document re-affirms current planning doctrine. At the same time, it provides an impetus for reconsidering parts of it in order to take account of change. The traditional image (since the report of the Working Commission on the Western Netherlands) of the Green Heart as a rural counterpart of a metropolitan area has disappeared. Instead, Randstad and Green Heart form an integrated complex, the character of which is predominantly metropolitan. The Green Heart is now seen as the garden of an emergent green world city. The report couches its arguments for maintaining the Green Heart in terms of the preservation of the living and working environment of the Randstad. Without much ado, the inhabitants of villages and towns in the Green Heart now count as inhabitants of the Randstad. This offers a justification for maintaining the restrictive policy until 2010. The same argument also goes to silence inhabitants and firms complaining about inadequate housing, reduced levels of services and lack of employment due to a shortage of land for building homes, offices and industrial plants. According to the government, the inhabitants of the latest addition to the Dutch metropolis will have to get used to land being a scarce resource. This implies an end to concentric local growth. The resulting overspill from Green Heart communities will have to go to designated areas in the compact city regions. 
What is new is the intention to make optimal use of the unique opportunities offered by the location of urban as well as rural areas. On the one hand this implies the inter-weaving of urban and rural elements (designated as "red" respectively "green" in Dutch planning jargon). On the other hand, infrastructure links between the city regions of the Randstad along the fringes will be improved. Where the need should arise, this even applies to infrastructure traversing the Green Heart. (The document on the green metropolis came out together with a policy document of the Ministry for Transport, Public Works and Water Management concerning improvements to the accessibility of the Randstad.) Within the definite borders of the Green Heart, there will be a cap on any major housing development until 2010. Sites for the, according to the most recent estimates, approximately 115,000 additional homes needed between 2005 and 2010, together with the 1,300 hectares of industrial land, must be found on the Randstad ring. Over a period of 25 years, there is a need for extra investment in the "green" and "blue" infrastructure. This comes on top of the 2,200 million guilders already set aside by the government and the provinces for 14 strategic "green" projects. "Blue" infrastructure refers to a network of lakes, rivers and canals in the Green Heart designated to be developed for recreation, drinking water supply and the creation of aquate nature (Comprehensive summary, 1991). There is a need for more coordination between decisions concerning projects in the Green Heart and decisions concerning open space elsewhere in the Randstad. Until now, organizational and procedural barriers have stood in the way of such coordination.

Flanking strategies are designed to improve communication. Comprising only ministerial and provincial representatives, the Green Heart Steering Committee has been abolished. It has failed to generate support for projects among politicians and inhabitants of the Green Heart. It is replaced by a broader Green Heart Platform (Bestuurlijk Platform Groene Hart). There, representatives of ministries, provinces, municipalities, water boards and action groups meet on a regular basis. The new Platform is expected to generate consensus concerning "green" projects. The Platform will have to coordinate investment decisions with another new Randstad Commission (Bestuurlijke Commissie Randstad). The Randstad Commission comprises representatives of the provinces of South Holland, North Holland, Utrecht and Flevoland, together with the city regions of Amsterdam, Rotterdam, The Hague and Utrecht.

Concerning the period after 2010 , the government contemplates a break with the established policy of building exclusively on or near the Randstad ring. The choice will be between more overspill to the North, the East (Gelderland) and/or to the South (Brabant and Zeeland).

These recent developments lend support to Korthals Altes arguing that Dutch planning doctrine develops in evolutionary fashion. We approve of this, but at the same time there are areas of legitimate concern. The approval concerns the preservation of a long-established principle that has every potential of continuing to be useful. That there is still open space left in the West is undoubtedly the merit of the Green-Heart policy. The Green-Heart policy has been a cornerstone of national urban policy. Consider the covenants between the national government and the city 
regions under the Fourth Report Extra. In the eyes of foreign observers it must be nothing short of a miracie that, even though government grants are substantially less, the city regions have been willing to make such far-reaching deals with the government.

Our concern relates to whether the present policy is realistic considering societal problems on the one hand and the available instruments on the other (National Spatial Planning Agency, 1995). For instance, consider the lack of suitable industrial land on the ring of the Randstad. Add to that the growing phenomenon of traffic criss-crossing between towns and villages within the entire metropolitan area.

Figure 3 Recent threats to the Green Heart

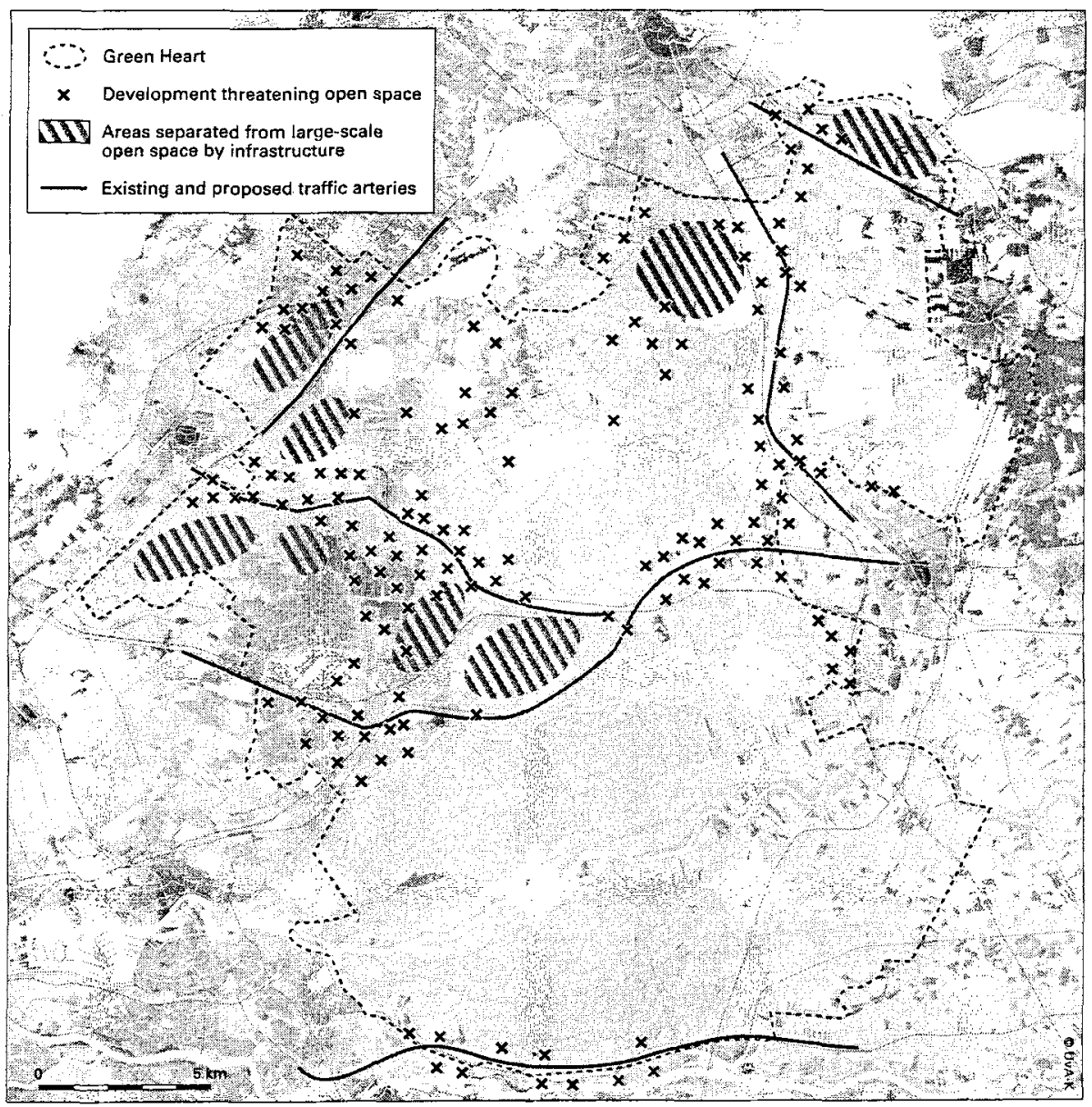

Source: Rijksplanologische Dienst, 1996 b, p. 89. 
Consider the pressing requirement for affordable building land in the great cities. And we should not forget the growing need for land for market gardening! Finally, consider the vulnerable position of arable farming and animal husbandry. As against this, consider the much-reduced government investment in housing! Firm language alone does not solve problems. The opposite may be true. Unfulfilled promises can undermine the credibility of policy, as well as that of the professional planning community.

\section{Conclusion}

In 1990 we expressed fears about the future of the Randstad-Green Heart concept. Within the planning community the admirers of the Los Angeles model of urban sprawl got much publicity. This we interpreted as the genesis of anomalies within the existing doctrine. So a revolution seemed on the cards. However, this is no longer the case. The outcome of the Green Heart debate again proves the sustainability of existing planning doctrine. The conditions as set out by Korthals Altes for a re-evaluation of traditional concepts are met. What we are witnessing is manifestly gradual change.

\section{References}

Ahsmann, R., and W. Zonneveld (1990) "Het Groene Hart; dertig jaar een gebrekkige visie", Rooilijn (23), no. 6, pp. 157-164.

Alexander, E.R., and A. Faludi (1990) "Planning doctrine: Its uses and applications", Working Papers of the Institute for Planning and Demography, no. 120, Amsterdam: University of Amsterdam.

Boer, M. de (1995) Milieu, ruimte en wonen; tijd voor duurzaamheid, The Hague: Ministry of Housing, Spatial Planning and Environment.

Burke, G. L. (1966) Greenheart Metropolis: Planning the Western Netherlands, London, Melbourne, Toronto: Macmillan.

Comprehensive summary (1991) Fourth report (Extra) on physical planning in the Netherlands; On the road to 2015, The Hague: Department for Information and International Relations of the Ministry of Housing, Physical Planning and the Environment.

Faludi, A. (1987) A Decision-centred View of Environmental Planning, Oxford: Pergamon.

Faludi, A., and A.J. van der Valk (1990) De groeikernen als hoekstenen van de Nederlandse ruimtelijke planningdoctrine, Assen: Van Gorcum.

Faludi, A., and A.J. van der Valk (1994) Rule and Order: Dutch Planning Doctrine in the Twentieth Century, Dordrecht: Kluwer Academic Publishers.

Foley, D.L. (1963) Controlling London's Growth: Planning the Great Wen 1940-1960, Berkeley CA: University of California Press. 
Friedmann, J., and C. Weaver (1979) Territory and Function: The Evolution of Regional Planning, London: Edward Arnold.

Garreau, J. (1991) Edge City: Life on the New Frontier, New York: Doubleday.

Glasbergen, P., and J.B.D. Simonis (1979) Ruimtelijk beleid in de verzorgingsstaat: onderzoek naar en beschouwing over de (on)mogelijkheid van een ruimtelijk beleid in Nederland, Amsterdam: Kobra CV.

Hall, P. (1966) The World Cities, London: Weidenfeld and Nicholson.

Jaarverslag 1961 (1962) Rijksdienst voor het Nationale Plan, The Hague: Sdu.

Jaarverslag 1962 (1963) Rijksdienst voor het Nationale Plan, The Hague: Sdu.

Korthals Altes, W.K. (1995) De Nederlandse planningdoctrine in het fin de siècle: ervaringen met voorbereiding en doorwerking van de Vierde nota voor de ruimtelijke ordening (Extra), Assen: Van Gorcum.

Kuhn, T.S. (1970, first edition 1962) The Structure of Scientific Revolutions, Chicago: University of Chicago Press.

Laudan, L. (1982) "Two puzzles about science: reflections on some crises in the philosophy and sociology of science", Minerva (20), nos. 3-4. pp. 253-268.

Laudan, L. (1984) Science and Values: The Aims of Science and their Role in Scientific Debate, Berkeley CA: University of California Press.

National Spatial Planning Agency (1995) Spatial Planning in the Netherlands; Bodies and Instruments, The Hague: Ministry of Housing, Spatial Planning and Environment.

Needham, B. (1995) De gronden van ons bestaan; ruimtelijk beleid voor een klein, dichtbevolkt land, Nijmegen: PIN Katholieke Universiteit van Nijmegen (University of Nijmegen).

Randstad en Groene Hart: de Groene Wereldstad (1996) The Hague: Sdu. (Handelingen Tweede Kamer 1996/97 25009 no. 1.)

Rein, M., and D. Schön (1986) "Frame-reflective policy discourse", Beleidsanalyse (15), no. 4, pp. 4-18.

Rijksplanologische Dienst (1996a) Ruimtelijke verkenningen 1996; jaarboek Rijksplanologische Dienst, The Hague: Ministry of Housing, Spatial Planning and Environment.

Rijksplanologische Dienst (1996b) Het Groene Hart in woord, beeld en getal; achtergronddocument Groene Hart gesprekken, The Hague: Ministry of Housing, Spatial Planning and Environment.

Rijksplanologische Dienst (1996c) Nederland 2030 tussenbalans; verkenning ruimtelijke perspectieven, The Hague: Ministry of Housing, Spatial Planning and Environment.

Schön, D.A., and M. Rein (1994) Frame Reflection: Toward the Resolution of Intractable Policy Controversies, New York: Basic Books.

Van der Valk, A.J., and A. Faludi (1992) "Growth regions and the future of Dutch planning doctrine", in Batey, P.W. (ẹd.), Sustainable Development and Urban Form, pp. 122-137, London: Pion Ltd.

Verslag van de Groene Hart Gesprekken (1996) Ruimte, groen en water voor iedereen, The Hague: Ministry of Housing, Spatial Planning and Environment. 
VINO a (1988) Vierde nota over de ruimtelijke ordening, deel a: beleidsvoornemen, The Hague: Sdu. (Handelingen Tweede Kamer 20490 nos. 1-2.)

Werkcommissie Westen des Lands (1958) De ontwikkeling van het Westen des Lands: toelichting, The Hague: Sdu.

Zonneveld, W. (1991a) Conceptrorming in de ruimtelijke planning: patronen en processen, Amsterdam: Institute for Planning and Demography, University of Amsterdam. Planologische Studies No. 9A.

Zonneveld, W. (1991b) Conceptvorming in de ruimtelijke planning: encyclopedie van planconcepten, Amsterdam: Institute for Planning and Demography, University of Amsterdam. Planologische Studies No. 9B.

\section{About the authors}

Arnold van der Valk is an Associate Professor at the Faculty of Environmental Sciences and the Amsterdam Study Centre for the Metropolitan Environment (AME) of the University of Amsterdam.

Andreas Faludi is a Professor of Planning at the Facuity of Environmental Sciences and Chairman of the Board of the Amsterdam Study Centre for the Metropolitan Environment (AME) of the University of Amsterdam. 